\title{
DECENTRALIZING REVENUE IN THE CONTEXT OF FISCAL DECENTRALIZATION: CHALLENGES, AND PROSPECTS IN UKRAINE
} ДЕЦЕНТРАЛІЗАЦІЯ ДОХОДІВ У КОНТЕКСТІ ФІСКАЛЬНОЇ
ДЕЦЕНТРАЛІЗАЦІї: ВИКЛИКИ ТА ПЕРСПЕКТИВИ В УКРАЇНІ

\begin{abstract}
At present, the issue of reforming the financial system to meet current requirements, further redistribution of local revenue and capacities for the benefit of local government and changes in the structure of intergovernmental transfers is being discussed at all tiers of government, in a scientific environment and in public sector. This article explores the fiscal decentralization in terms of revenue distribution in Ukraine, reviews its 2014-2019 course, and explores the conditions, problems, and prospects on the advancement of the revenue assignments for local budgets in the process of fiscal decentralization. Based on the theoretical discussion, coverage of content on the decentralization trend in Ukraine, working between theoretical approaches and literature analyses on decentralization of revenues specifically, we offer suggestions about the implication of practices on distribution of powers to local governments and conclude with recommendations for further research. In addition, in our opinion, today in Ukraine the institution of local self-government is not considered as politically independent, sufficiently from the decisions of the state government. Local government still lacks common mechanisms and experience to stimulate the local self-government to independently collect taxes and establish their basic level, launch fiscal decentralization, assign revenues, and increase own tax potential to ensure a decent quality of life within the subordinate territories. Changes to the budget and tax legislation, which came into force in 2015, have encouraged local authorities to expand their own revenue base, but the increase in the degree of fiscal decentralization of local budgets in recent years has been slow enough. The degree of fiscal decentralization in Ukraine remains low prevails centralized balancing of inter-budgetary relations.

Key words: fiscal decentralization, revenue decentralization, revenue distribution, local government.
\end{abstract}

Сьогодні питання рефрормування фрінансової системи задля задоволення вимог часу, подальшого перерозподілу місцевих доходів і потужностей на користь органів місцевого самоврядування та зміни структури міжбюджетних трансфертів обговорюється на всіх рівнях влади, в науковому середовищі та в громадському секторі України.

Автор статmі, охоплюючи теоретичн підходи, аналіз літератури, досліджує перебіг фрінансової децентралізації в аспекті розподілу доходів у 2014-2019 роках. у статті розглянуто сучасний стан, проблемні питання та перспективи розвитку тренду розмежування доходної частини місцевих бюджетів у процесі фрінансової децентралізації в Україні. Висвітлено зміст і тенденції, розглянуто основні показники децентралізації доходів $і$ запропоновано рекомендації щодо подальших змін.

Крім того, на нашу думку, сьогодні в Україні інститут місцевого самоврядування не розглядається як політично автономний, самодостатній, незалежний від рішень центральної влади. У місцевого самоврядування досі немає загальних механізмів i реального досвіду самостійно обирати належні ставки місцевих податків і встановлювати їхній базовий рівень, проводити ефрективну фрінансову децентралізацію, призначити доходи та збільшувати власний податковий потенціал для забезпечення гідної якості життя на підпорядкованих територіях.

Отже, зміни, внесені до бюджетного та податкового законодавства, які набули чинності у 2015 році, спонукали місцеві органи влади розширити власну дохідну базу, але зростання ступеня фіскальної децентралізації місцевих бюджетів в останні роки відбувається досить повільно. Ступінь фісккальної децентралізації в Україні залишається низьким, переважає централізоване збалансування міжбюджетних відносин.

Ключові слова: фрінансова децентралізація, децентралізація доходів, розмежування доходів, місцеві органи влади.
Problem formulation. At present, fiscal decentralization of local budgets in Ukraine involves overcoming the dependence of local communities on the state government, financial weakness and high subsidy, degradation of rural territories, as well as a low level of investment attractiveness. It is necessary to clearly distinguish between the local government own sources of revenue and borrowed sources with appropriate methods of their calculation.

Moreover, the local authorities finance educational, health, science and culture programs, which all correlate per person residing in a particular territory or an enterprise located in it has financial obligations in accordance with financial conditions. These costs are enormous, therefore, they must be evenly distributed to all residents and businesses on the area, taking into account own tax potential.

These challenges are predetermined by limited functional powers performed by the local government, the scope of responsibility and sources of financial resources, and due to the 
lack of interest of the authorities of the central government in limiting own powers and reducing the sources of financial resources.

Analysis of recent research and publications. Today, the problem of developing an effective budget mechanism that defines new principles for the formation of local budgets, a clear delineation of the powers of all governmental levels, and hence the expenditures of all tiers of budgets and, most importantly, revenues between different brunches of the budget system, that is especially acute. Fiscal decentralization trend, as a rule, includes the redistribution of budget functions between levels of government, as well as changing the boundaries of the financial competence of the local government and other tiers of government; it enables local authorities to take the initiative, to search for sources of local needs better satisfaction.

Recently, the aspect of ongoing reform causes the great number of disputes, attracting special attention of scholars. Recently, scholars examine the expenditure decentralization, revenue decentralization, and institutional decentralization [2; 20]. Researchers explore the features of the development of fiscal decentralization in different countries of the world [8], assessment of the trends in the advancement of decentralization of the budget system [1]. Scholars also define the fiscal decentralization and budget structure of the country [2], the role of intergovernmental relations in the system of government [19], the realities of fiscal decentralization in Ukraine $[6 ; 15 ; 16]$, decentralization and financial support of communities - hromada [3;4]. The others are examining the economics of measuring fiscal decentralization $[1 ; 20]$, the influence of decentralization on dynamics of income of local budgets [8; 13], revenue decentralization and income distribution [5; 12].
Therefore, the issue of revenue decentralization of local budget, main indicators of income decentralization as a degree of independence of local budgets in the process of fiscal decentralization needs further investigation.

The purpose of the article is to clarify the content, issues and practical recommendations on the fiscal decentralization of local budget in terms of revenues distribution in Ukraine.

Highlighting previously unresolved issues of a common problem. Obvious that excessive fiscal decentralization and, as a result, the excessive desire of local authorities to maximize their budget revenues can lead to negative effects. Among them - an increase in the tax burden and the destruction of a single economic space of the country, since in most hromada the local deputies are business representatives or closely related to business circles - hence lobbying own business interests. At the same time, it seems to us that balanced fiscal decentralization has a positive effect on a number of macroeconomic indicators. First, it is synonymous with the economic development of the territory.

Second, until now there is no commonly accepted method for measuring revenue decentralization in Ukraine, different approaches lead to different results, especially for countries in a transition economy. The most common indicators for evaluating decentralization are shown and calculated below, are as follows (tab. 1).

Third, the analysis of the expenditure share of local budgets indicates that budgets are close in terms of cost composition, and possess significant differences in the structure of revenues [11].

The tendency in 2013, 2015, and 2018 shows the more than $52 \%$ share of interbudgetary transfers and indicates the state government centralizes the balances of the local

Transfers and the indicators of revenue decentralization

Table 1

\begin{tabular}{|c|c|c|c|}
\hline \multirow{2}{*}{ Indicator } & \multicolumn{3}{|c|}{ Year, \% } \\
\hline & 2013 & 2015 & 2018 \\
\hline the share of inter-budgetary transfers in the local budget revenues & 52.4 & 59.1 & 53 \\
\hline the share of tax revenue in total local budget revenue & 42,0 & 33,3 & 43.2 \\
\hline the share of local tax and fees in the local budget revenues & 3,3 & 9,2 & 10,9 \\
\hline the share of local revenues in the consolidated budget revenues & 50 & 45 & 48 \\
\hline the share of own revenues in the local budget revenues & 47,6 & 40,9 & 46.8 \\
\hline $\begin{array}{l}\text { the share of inter-budgetary transfers in the state budget from local } \\
\text { budgets }\end{array}$ & 0.7 & 1.1 & 1.3 \\
\hline
\end{tabular}

Calculated by the author based on the annual budget reports by the State Treasury Service of Ukraine [17; 1]. 
budget revenues. The share of inter-budgetary transfers in the state budget from local budgets increased from $06 \mathrm{pp}$. from 2013 to 2018, i.e., the withdrawal of funds from local budgets to the state is increasing. The above calculations show that yet no significant changes in the direction of strengthening fiscal decentralization have occurred. In particular, local budget revenues in the consolidated budget (a key indicator of decentralization according to some scholars) continue to be insufficient in 2018 to support intensive decentralization processes, it is $48 \%$, and is lower than in $2013-50 \%$. In addition, the degree of fiscal autonomy of local communities in Ukraine is decreasing, and the structure of local budget revenues does not contribute to the innovation and investment development of local communities [1]. Nevertheless, the competence in the area of local revenue distribution is still not clearly defined, which does not ensure selfgovernment at all tiers of government to manage the local finance. Therefore, these days the changes providing for fiscal decentralization and assigning are reduced mainly to a revision of the local revenue share and mostly per increase of local taxes

Main statements. The distribution of powers between budgets to a certain extent depends on the state structure of the country. The state system creates the construction of the budget system of the country, determines the number of its levels. The presence of two or more levels of the budget system requires the dividing of budgets into state and local [19].

In its content, fiscal decentralization is a transfer of powers. Moreover, this is a legislatively fixed strategy for the distribution of powers and responsibilities of state, regional, local authorities with a compromise differentiation on revenue (revenue decentralization) and expenditures (expenditure decentralization) between tiers of the budget system based on political activity, social ethics, inter-regional and interethnic solidarity.

To continue, per all the national features the priority of local self-government is the stateguaranteed right of territorial units - hromada to independently resolve general economic issues of local importance based on the real financial sources and in the framework of adopted laws and general rules. In the context of fiscal decentralization, legislative provisions, and independent formation and usage of the local budget, the direct selectivity of government by the local citizens, and the regular reporting of local government to the population of the territorial unit determine the independence of local governments. From now on, fiscal reform has significantly increased the revenue share of local budgets. However, at the same time, most of the costs related to the everyday life routine of local communities are now being financed from the local budgets.

Local governments' own revenues include revenues of local budgets that are omitted in determining the number of intergovernmental transfers - tax and non-tax revenues, revenue from capital transactions, as well as trust funds of local governments. The value of own local budget revenues in the last three years ranges from 44-48\% of total local budget revenues. In 2018, local budget revenues came to UAH 563.4 billion, of which UAH 263.5 billion were own revenues and UAH 298.9 billion were shifted from the state budget [17].

Own revenues of local budgets are shaped by 1) tax revenues; 2) non-tax revenues; 3 ) other revenues: fixed capital, trust funds, and donations from the EU and international organizations, etc. Fixed-income local governments, which also include tax and non-tax revenues, income from capital transactions, which are omitted in determining the number of intergovernmental transfers.

In addition to own and assigned revenues, regulatory revenues, which according to the Budget Code of Ukraine are attributed to: 1. Equalization grants provided by the state for horizontal alignment of taxation capacity of local communities play an important role in shaping the revenue share of local budgets. 2. Extra subsidies to offset lost revenues from local budgets in connection with state-level benefits. 3. Subventions that assigned as for a specific purpose and according to a certain algorithm determined by the authority that has decided to grant a subvention to a specific local community. These include, in particular, investment and infrastructural, medical and educational subsidies. All of the subsidies basic and additional subsidies together with a subvention represent in the aggregate transfers of the state budget to local budgets. In addition, the World Bank attributes regulatory subsidies to local budget revenues, which are funds transferred from the local budget to the state for horizontal alignment of the solvency of the territories.

Furthermore, another source of local budget revenue generation is borrowed financial resources generated via the issuance of local debt bonds and loans. Unlike inter-governmental transfers, such resources are supplied to local budgets in compliance with the basic principles of lending - the purpose, timely tracking, security, and return. 
Briefly, among other revenues of the hromada, the legislation proposes targeted and voluntary contributions of enterprises, institutions, organizations and citizens to local environmental funds; proceeds from other trust funds. Thus, since 2015, a new budget model has been introduced in Ukraine, aimed at ensuring fiscal decentralization, namely increasing the number of financial resources at the disposal of local governments and forming financially viable local communities [9; 10].

Conclusions and prospects for further research. Changes to the budget and tax legislation, which came into force in 2015, have encouraged local authorities to expand their own revenue base, but the increase in the degree of fiscal decentralization of local budgets in recent years has been slow enough. The degree of fiscal decentralization in Ukraine remains low prevails centralized balancing of inter-budgetary relations.

Thus, the study of fiscal decentralization has produced the following results: 1 . Optimize the ratio of tax and non-tax revenues by increasing the hromada own income: - expand the range of services that may be provided by public institutions in accordance with the law; - actively lease state property; - strengthening control over the imposing the state duty when concluding donation and inheritance agreements; stimulate active business activity. 2 . Increasing tax revenues by simplifying and strengthening the tax collection system, controlling tax rates, controlling conflicts of interest, preventing lobbying business motivation. To regularly carry out public hearings on local taxes and fees, which do not occur in most communities, although this could be a tool for working with deputies and business representatives to raise tax rates.

The results of the analysis made it possible to outline the need for further research in the direction of assessing GDP trends in terms of fiscal decentralization in order to scientifically substantiate the conceptual foundations for improving its effectiveness.

\section{REFERENCES:}

1. Agayan Sh., Muradova S. and Bahdasaryan L. Assessment of trends in the development of fiscal decentralization in the budget system of the Russian Federation. Management of economic systems : an electronic scientific journal. 2015. Accessed August 01, 2019. URL: https://cyberleninka.ru/article/n/otsenka-tendentsiy-razvitiya-fiskalnoy-detsentralizatsii-v-byudzhetnoy-sisteme-rossiyskoy-federatsii.

2. Boryslavskaya O., Zaverukha I., Zakharchenko E., et al. Decentralization of public authority: the experience of European countries and prospects Ukraine. SwissUkrainian project "Support for Decentralization in Ukraine - DESPRO". Kyiv : LLC "Sofia", 2012. 128 p.
3. Cheberyako $\mathrm{O}$. and Ryabokon $\mathrm{O}$. The Impact of Fiscal Decentralization on the Formation of Local Budgets. University Economic Bulletin. 2017. № 32 (1). P. 316-326.

4. Chubar O. and Mashiko K. Decentralization and financial support of the territorial community. Uzhgorod University Scientific Bulletin. 2016. P. 419-426.

5. Fretes Cibils V. and Ter-Minassian T. Decentralizing Revenue in Latin America Why and How. Executive Summary. Inter-American Development Bank. 2015. 17 p.

6. Lunina I. Development of Budget Decentralization in Ukraine : Scientific Report. Kyiv : National Academy of Sciences of Ukraine. State Enterprise "Institute of Economics and Forecasting", 2016. DOI: ISBN 978966-02-7900-1.

7. Malinovskaya $O$. and Brovkina A. Budgetary decentralization : the state and features of development in the Russian Federation at the present stage. Finance and credit. 2012. № 15 (495). P. 20-29.

8. Marchuk A. Influence of decentralization on the structure and dynamics of income and expenditures of local budgets. Finance World. 2018. № 2 (55). P. 20-31.

9. Ministry of Finance of Ukraine. Budget programs passports. Accessed July 31, 2019. URL: https://www. minfin.gov.ua/news/pasporty-biudzhetnykh-prohram.

10. Ministry of Regional Development, Construction and Housing, and Communal Services in Ukraine. Decentralization in Ukraine. Accessed July 13, 2019. URL: https://decentralization.gov.ua/news/4913.

11. Nekhaychuk D. and Nekhaychuk Y. Financial Decentralization of Local Self-Government: Modern Challenges. Accessed August 05, 2019. URL: http:// dspace.nbuv.gov.ua/bitstream/handle/123456789/ 92884/08-Nekhaychuk.pdf?sequence=1

12. Neyapti B. Revenue decentralization and income distribution. Economics Letters. 2006. № 92. P. 409-416.

13. Ostrovetskyy V. Fiscal policy of Ukraine in the conditions of decentralization: revenue of local budgets. Donbas Economic Bulletin. 2017. № 4 (50). P. 82-88.

14. Sabitova $N$. To the issue of reforming the budget process in the Russian Federation. Finance and credit. 2006. № 6. P. 69-73.

15. Serebryanska D. The Guidelines to Improve the Distribution of Expenditure Responsibilities in the System of Local Authority. Economics and Forecasting. 2014. № 3. P. 83-92.

16. Serebryanska D. Distribution of expenditures between levels of local budgets under conditions of budget decentralization Author's abstract, Ph.D. diss. Kyiv : IEPNANU, 2015. 21 p.

17. State Treasury Service of Ukraine. Execution of the State Budget. The official website. URL: https:// www.treasury.gov.ua/en/file-storage/richnij-zvit-provikonannya-derzhavnogo-byudzhetu-ukrayini-za-2018-rik.

18. The Budget Code of Ukraine. 2010. July 08, 2010. № 2456-VI.

19. Vladimirov V. Influence of Budget Policy on Inter-budget Relations. Baikal Research Journal. 2016. № 7 (4). Accessed July 27, 2019. URL: https:// cyberleninka.ru/article/n/vliyanie-byudzhetnoy-politikina-mezhbyudzhetnye-otnosheniya.

20. Yushkov A. Fiscal decentralization and regional economic growth: Theory, empirical studies, and Russian experience Leontief Centre. 2016. № 2. P. 94-110. 